\title{
Registration of 'AMBERICHO' a Newly Released Field Pea (Pisum sativum L) Variety for the Southern Highlands of Ethiopia
}

\author{
Yayis Rezene ${ }^{1}$, Fitsum Alemayehu ${ }^{2}$, Fikadu Gurmu ${ }^{2}$, Fisseha Negash ${ }^{1}$, Bahilu Banteyirgu ${ }^{1} \&$ Yasin Goa $^{1}$ \\ ${ }^{1}$ Areka Agricultural Research Center P. O. Box 79 Areka, Ethiopia \\ ${ }^{2}$ Awassa Agricultural Research Center P. O. Box 06 Hawassa, Ethiopia \\ Correspondence: Yayis Rezene, Areka Agricultural Research Center P. O. Box 79 Areka, Ethiopia. E-mail: \\ rezene77@gmail.com
}

Received: December 18, 2014 Accepted: April 6, 2015 Online Published: April 16, 2015

doi:10.5539/jps.v4n2p42

URL: http://dx.doi.org/10.5539/jps.v4n2p42

\begin{abstract}
Ambericho (IG-51664) with a large and white seeded field pea variety was selected and developed by Areka Agricultural Research Center, southern Ethiopia. This variety was selected from the regional variety trial tested together 15 other test genotypes including local and standard checks at 8 environments. Finally the variety was officially released for wider production in the southern highlands of Ethiopia.
\end{abstract}

Keyword: Ambericho, variety, field pea

\section{Introduction}

Field pea (Pisum sativum L.) is an annual climbing, herbaceous plant, showing very considerable variation in form and habit. It is probably originated in south-western Asia and has spread to the temperate zones throughout the world and is grown as a cool season crop in sub-tropics, and the higher altitude in the tropics. It requires a cool; not excessively cold climate, evenly distributed a rainfall of about $800-1000 \mathrm{~mm} /$ annual and cultivated in wide range of soil type with PH range 5.5-6.5 provided that the derange is good (Key, 1979). In Ethiopia field pea with other pulse covers a wide range of about $11-15 \%$ of the total 6-7 million hectares of the area and is the third most important staple food legume among the highland pulses (CSA, 2009). The estimated annual consumption of field pea per person in rural Ethiopia is 6kg in form of spilt, milled and unmilled (Asfaw et al., 1994). Field pea is nutritious food staff when fully matures and they are valuable food legume, often being ground in to flour and used extensively in the manufacture of soups. Fresh green peas are almost universally accepted as nutritious vegetable. Green peas are in fact the leading processed vegetables; a large quantities being grown for canning, freezing or dehydrating (Kay, 1979). Asfaw et al (1994) indicated that field pea is a 'break' crop with the cereal rotation, especially with barley and wheat, which serves to restore soil nitrates and minimize weeds, insects pest and disease of cereals.

\section{Methodology}

Around 100 lines were acquired from Holetta Agricultural Research Center in 2002 and tested as nursery at Location Angacha for one year. Out of the tested lines of field pea 16 materials were screened for yield and agronomic traits in randomized complete block design in 2005 and 2006 in multi-location yield test within the southern region at Angacha, Hossana, Waka and Bule major pea growing areas. All the materials were evaluated together with local check and 'Tegegnech' standard check in a total of eight environments. The elite line with pedigree IG-51664 was named AMBERICHO after official release for commercial production by the national seed releasing committee.

\section{AMBERICHO}

AMBERICHO is common name for the field pea variety with the pedigree name of IG-51664. It is developed and released by Areka Agricultural Research Center for major field pea growing areas of Southern Ethiopia. Ambericho was evaluated for two years (2004-2005) at Angacha, Hossana, Waka and Bulle stations and had better mean grain yield than the standard check. Ambericho was moderately tolerant to ascochyta blight and powdery mildew. It has creamy white seed coat colour with no black spot and with smooth round seed character. The result of multi-location trials showed that Ambericho had above-average grain yield performance across tested locations and years. 


\section{Reference}

Asfaw, T., Beyene, D., \& Tesfaye, G. (eds). (1994). Genetics and breeding of field pea, pp. 122-137. Cool-season Food Legumes of Ethiopia. Proceedings of the First National Cool-season Food legumes review conference, 16-20 Dec 1993, AA. IAR/ ICARDA, Alppeno.

CSA (Central Statistical Authority). (2009). Agricultural sample survey, area and production of temporary crops, private holdings for the 2007/08 Meher season.

Kay, D. E. (1979). Crop and Product Digest. No. 3- Food legumes (p. 435). London: Tropical Products Institute, XVI.

\section{Copyrights}

Copyright for this article is retained by the author(s), with first publication rights granted to the journal.

This is an open-access article distributed under the terms and conditions of the Creative Commons Attribution license (http://creativecommons.org/licenses/by/3.0/). 